\title{
A CONFLUENCE OF POLITICAL ECONOMY AND AUDIENCE SELECTIVITY ON HAUSA VIDEO FILM PREFERENCES AMONG THE YOUTH OF KAWO AND UNGUWAN DOSA AREAS OF KADUNA METROPOLIS
}

\author{
Binta Kasim Mohammed, $\mathrm{PhD}$ \\ Department of Mass Communication \\ Faculty of Social sciences \\ Kaduna State University, Kaduna \\ +2348036873577 \\ dr.bkmohammed@gmail.com
}

\begin{abstract}
This paper studies the preferences of the content and genres of Hausa video films through a quantitative survey of young people selected from Kawo and Unguwan Dosa areas of Kaduna metropolis using quota, simple random and convenience sampling techniques. Semi-structured questionnaires were self-administered to a sample of 200 but only 189 were valid. The findings reveal that despite the incessant criticism of the Hausa film industry over its dependence on romantic genres, it was the most preferred among the respondents. Other factors such as the song and dance numbers were also a major attraction for viewership among the youth alongside love for popular actors and their dressing followed by the appeal of advertised film trailers. This paper concludes that the audience members are not as passive as assumed and that the market domination of films with romantic content is both to satisfy audience demand and also make profit. It is observed that overexposure to certain genres/contents during socialization may have contributed to youth perception and preference. The paper recommends that film producers should strategically utilize the most preferred genres and actors to address important social challenges and also promote positive aspects of the indigenous Hausa culture.
\end{abstract}

Key words: Hausa video film, Preference, Confluence, Political Economy, Audience, Selectivity

\section{INTRODUCTION}

The ongoing Information and Communication Technology revolution of the $21^{\text {st }}$ century has led to the emergence of so many sophisticated gadgets that are taking the world by storm, continuously redefining the mass media and creating unavoidable overlaps of media and audience. The result is a never before seen information and entertainment bombardment, including a dependency on the media for most needs.

Within a single generation, homes have become media-rich, with multiple televisions, radios, games machines, computers, music systems and telephones, these typically shifting from household possessions to personal possessions, accompanying us wherever we go. In our everyday engagement with friends and family, with the community, the political system, the nation and beyond, we draw upon, and we increasingly rely upon, a never-ending flood of images, ideas and information about worlds distant in space or time and about the world close to home. (Livingstone, 2005: P1)

Some mass media historians (Drotner, 1992; Cohen,1972; Pearson,1983) all cited in Livingstone (2005) point out that each time a new medium emerges in a society, the same set of concerns and criticisms also emerge over its operations, content and audience. Social voices go into what Cohen (1972) describes as 'Moral Panic' where scholars, the clergy, opinion leaders and social groups all rise to decry violence, nudity, exploitation, media 
reinforcement and cultivation of unattractive attitudes. According to Dotner (1992), the society goes through a 'historical amnesia' engaging in the usual 'media blame game' each time a new medium emerges forgetting that same concerns accompanied the media that preceded the latest one and it never stopped it from being incorporated into social life (Livingstone, 2005).

The concept of the audience has always been passionately discoursed and debated from many different perspectives. In the early years of media research, the media audience were assumed to be almost passive and then eventually scholars arrived at the acknowledgement of the 'active audience' and their power of choice over what media content to access or react to. The first group of audience researchers are the reception scholars who are concerned with meaning making of media content, the behaviour of the audience towards media messages and audience selectivity. The second group are critical scholars who are somewhat intrigued at the audience's inability to recognise propaganda and their willingness to be used as pawns in a struggle for market domination by media organisations. The third group are the effect scholars that are concerned with audience cultivation and other effects of media messages on the individual and also the society (Gillespe, 2005; Livingstone, 2005).

The Selectivity Theory of Mass Communication confers a lot of power on the audience who possess the choice to select which media genre and content they choose to expose themselves to. The theory buttresses the concept of the active audience that is capable of influencing or deciding what type of content, at which times and on which channels the mass media transmits to them (Baran and Davis, 2011, Cohen, 1972; Hall, 1980). Many other researchers however found out that because people typically encountered like-minded perspectives, the media mainly reinforced attitudes rather than changing them (Knobloch-Westerwick, 2015; Stroud, 2017).

On the other hand, most Political economy scholars, specifically those from media economics and media consumption (Adorno, 1991; Clark, 1998; Chomsky, 2002; Hesmondalgh, 2010) argue that media industries push certain genres and themes while purposively neglecting others. They further argue that the aim behind this is to sell an ideology and make profit but the audience swallows what they are fed line, hook and sinker.

This paper has the objective to find out the content preferences of the Hausa video film audience and the implication of these preferences on the production genres and contents of Hausa video films through the following research questions:

- RQ1. What are the preferred film genres among the youth of Unguwan Dosa and Kawo, Kaduna?

- RQ2. What are the motivating factors for consumption of Hausa video films among the youth of Unguwan Dosa and Kawo, Kaduna?

- RQ3. What is the preferred aspect of Hausa video film content among the youth of Anguwan Dosa and Kawo, Kaduna?

- RQ4. What are the implications of these preferences on the content of the Hausa video film industry? 


\section{LITERATURE REVIEW}

\section{The content of the Hausa video film industry}

The emergence of the Hausa video film industry (Popularly referred to as Kannywood) in the early 90s roused the dismay of cultural scholars and society at large towards the contents and genres of the industry's productions. The indigenous Hausa youth that grew up in the 70s and 80s exposed to Hindi cinema laid the foundations of the Hausa language video film industry based on their individual ideals (Ali, 2003; Jibril, 2003; Maikaba, 2003). Over the three decades of Kannywood's existence, the industry has produced thousands of video films in most popular global film genres such as romantic comedies, romantic drama, horror, mystery, historical and action (Adamu,2006).

Irrespective of genre, most or all of these films are characterised by the dominant theme of love and its struggles, revolving around forced marriage, rich boy meets poor girl or vice versa, love triangle etc. Such themes do occur in indigenous Hausa society, though albeit rarely because the reality in Hausa society is very far from the realities that have given rise to the love theme in Hindi Indian society (Adamu, 2005; Jibril, 2003; Maikaba, 2003). Indian society is known to have a culture that is repellent to romantic relationships before marriage and marriage based on love while favouring arranged marriages based on family ties and a favourable horoscope reading. The Hausa girl or boy is to a large extent allowed a choice of spouse and love is encouraged. This is evident in such cultural conducts that precede marriage such as Zance/Tadi (visit a suitor pays to a girl he likes), Toshi (monetary or other gifts regularly given to a girl after Zance), Kayan na gani ina so (gifts a suitor sends to a girl's family to show he likes their daughter and wants to take things to the next level) and Tambaya (official asking for a girl's hand in marriage). Decades into the industry's emergence, producers seem to widen their horizons to capture other forms of pre-and postmarital conflicts and challenges that are rooted in the typical Hausa social system such as child marriage and polygamy. However, the major themes of most Hausa film productions continue to revolve around romance and shallow domestic issues while other major social factors bedevilling Hausa society such as girl child education, Almajiranci and other cultural beliefs and practices holding the society back are neglected.

Another popular feature in Action Hausa films that is also typically disconnected from the Hausa culture is the depiction of the surreal Alpha male actor, capable of fighting dozens of adversaries hands down which is also an adaptation of actors in Bollywood productions. The strong man with a muscular body and suave moves is a common feature of American action films too, all typically inspired by the Chinese Kung Fu. A third popular film genre is the Chamama, which is comedy characterised by a lot of tomfoolery and mostly set in villages or lower class settlements. It is also a domestication of the foolish character that Hausa society refers to as the Chali chali who is a common appearance in most Bollywood films as a comic relief. A fourth genre are the historical or epics that the industry produces in a bid to silence the cultural adulteration criticism and showcase the ancient Hausa cultural and political system. The fifth are the industry's attempts at horror films revolving around witchcraft, spirits and mystery. Despite the turmoil and drawbacks experienced by the Hausa film industry, it has trudged on and even thriving in its appeal to a sizeable audience capable of sustaining its existence (Adamu, 2006; Maikaba, 2006).

\section{Media Consumption: Political Economy or Audience Selectivity}

Political economy focuses on the relationship between the economic structure, the dynamics of media industries and the ideological content of the media. The approach centres on market 
determination as a major influence on content (Chomsky, 2002; Hesmondhalgh, 2010). The relevance of political economy theory has been increased by several recent trends in the mass media; more powers being concentrated in fewer hands and the growing global information economy.

Political economy theorists investigate the means of production by looking at economic institutions expecting to find that these institutions shape media to suit their needs and purposes. The approach also looks at how power influences or biases the forms of mass culture produced and distributed through the media and how economic constraints influence or bias the forms of mass culture produced and distributed (Clark, 1998; Baran \& Davis, 2011). Political economists also examine the dominance of certain genres in media content and whether audience taste alone explains these choices or if there are other less obvious reasons. Some studies (Golding \& Murdock, 2000; Hesmondhalgh, 2010; Baran \& Davis, 2011) have ascertained over time beyond contest that regulations and economics are determinants of media content.

The only issue of contest among political economy scholars is the extent and level of this influence, varying with the media sector, the content and the environment the content is produced or consumed. Despite the extent of influence of regulation and economics on media content, culture industries have withstood the test of time and even progressively developed based on increased audience patronage. The consistent customer consumption of what critical political economists perceive as standardised, bland content produced using the same formula has intrigued them considerably (Clark, 1998; Baran \& Davis, 2011). According to Murdock and Golding, critical political economy argues that: "the process of ideological reproduction cannot be fully understood without an analysis of the economic concept within which it takes place, including the pressures and determinations where the concept exists" (Murdock and Golding, 1977, p.19).

Some media scholars (Furniss, 2003; Golding \& Murdock, 2000; Hesmondhalgh, 2010) have also observed that the financing, among other "power factors", determine mode of operations in a media industry, which in turn determines the final media product. The consumers of the end product are one of the major control factors that determine content. Political Economy scholars such as Horkhiemer and Adorno (1969) as cited in Laughey (2007) do not challenge the power of the audience to make a choice but argue that the availability of options within which the audience can make that choice is already constrained by the culture industries. Adorno (1991) further argues that during consumption the masses become characterised by the commodities which they use and exchange among themselves.

All the arguments above assume audience members to be an almost passive brainwashed group because they only have the right to choose within the confines of an already predetermined number of media content. The audience members are set up to believe they have the power to make a choice and therefore willingly use personal resources to choose among what is offered them instead of getting what they will have wanted. Chomsky (2002) in a bid to make sense of this intrigue argues that the audience of media content is like a 'bewildered herd' that cannot figure out propaganda imposed on it. The main defining feature of the culture industry for Adorno (1991) is "standardisation which refers not only to the culture industry products but its consumers too" (p.124). To Adorno, audiences have long since perceived and accepted the world as it is constructed for them by the culture industry 
and the content of the culture industry is purely mechanical reproduction and distribution for monetary gains (Laughey, 2007).

The postulations of the theory of Audience Selectivity, however, projects audience members as a group that have the power to choose what media content it exposes itself to. The concept of audience selectivity stems from the works of Lazarsfeld, Berelson, and Gaudet (1948) to trace audience exposure to the campaign messages of the United States 1940 presidential elections. Research in the area thrived for a while but became uncommon in the 70s and 80s. By the mid 80s up to the new millennium, research in the area got reactivated due to increase in media types and content. "Of recent the explosion of media choices (cable, Internet) has led to provocative theses about the possibility that the contemporary media environment may provide ideal conditions for selective exposure" (Stroud, 2017: p537).

Selectivity means the tendency to select that which interests the human mind. Pearson (1983) defines selection as "the process of neglecting some stimuli in the environment to focus on other stimuli" (1983: p.44). The basic processes of selectivity are first selective exposure and this is when a person exposes him/herself to information that reinforces rather than contradicts his/her beliefs or opinions. According to Pearson, under selective exposure there is selective attention, which means that we focus on specific cues and ignore others even when we expose ourselves to certain information (Fiske and Shelley, 1991; Pearson, 1983, Baran and Davis, 2011). Selective exposure is followed by selective perception which is the tendency to see and believe only what you want to see, hear and believe. The third stage in the selectivity process is selective retention which is the tendency to remember only what one deems important, i.e. what one correlates to his/her existing believes and values (Baran and Davis, 2011). Shroud (2017) proffers five reasons why selectivity takes place: cognitive dissonance, the seeking of supportive information, processing like-minded information requires less cognitive effort than processing uncongenial information, moods and emotions affect information search and because people believe that like-minded information is more credible and of higher quality.

This brief review looks at the two sides of media content determination argument: Political Economy and Audience Selectivity. At one juncture the power of the culture industry in socialization, limiting choices and influencing perception is glaring and on the other side is the audience that feels powerful in its ability to choose within the options which the industry presents to them. This need for media consumption is more pronounced than ever in this highly audio-visual and mediated twenty-first century society where the communication need competes with basic human needs such as food, sleep and sex. All of these needs continuously overlap over another without clear cut boundaries of where one ends and the other begins.

This paper assumes there must be a confluence where market forces meet with audience choice regarding the content and structure of Hausa video films which is the motivation for this study.

\section{METHODOLOGY}

This study is a quantitative survey of young people selected from Kawo and Unguwan Dosa areas of Kaduna metropolis using the quota, simple random and convenience sampling techniques. The two areas together have a dense population of indigenous Hausa people of all social groups and from all parts of Northern Nigeria second only to Rigasa area of Kaduna 
Volume 1 Number 1 Maiden Issue

Metropolis. There is a more than two kilometre U-shaped dual road (College Road, Kudan road and Sabon Birni Road) with streets on either sides from Unguwan Dosa to Kawo or vice versa leading to the major Ahmadu Bello way, Kaduna. This study was able to identify a total of 57 streets from beginning to end and used simple random sampling to select 20 streets. Semi-structured questionnaires were then self-administered to a sample of 200 young people between the ages of 15 and 30,10 respondents in each sampled street. The study ended up with189 valid questionnaires because 7 of them were incoherently completed while 4 got missing. Tables and simple percentages are used to present the data below.

\section{THE RESULTS}

- RQ1. What are the preferred film genres among the youth of Unguwan Dosa and Kawo, Kaduna?

Table 1: Preferred Hausa video film genres among respondents

\begin{tabular}{|l|l|l|l|}
\hline $\begin{array}{l}\text { HAUSA VIDEO FILM } \\
\text { GENRES }\end{array}$ & FREQUENCY & PERCENT & $\begin{array}{l}\text { CUMULATIVE } \\
\text { PERCENT }\end{array}$ \\
\hline Comedies & 64 & 33.9 & 33.9 \\
\hline Romantic drama & 81 & 42.9 & 76.8 \\
\hline Historical (Sarauta) & 17 & 8.9 & 85.7 \\
\hline Horror & 8 & 4.2 & 89.9 \\
\hline Action & 13 & 6.9 & 96.8 \\
\hline More than 1 option & 6 & 3.2 & 100.0 \\
\hline Total & 189 & 100.0 & 100.0 \\
\hline
\end{tabular}

The most preferred film genre among the respondents is Romantic drama which was chosen by $42.9 \%$ closely followed by comedy at $33.9 \%$. The Hausa comedy has become a very popular genre of recent, though mostly preferred by the elderly and less educated. Only $8.9 \%$ of respondents went for historical films while $11.1 \%$ preferred action and horror films. Over the years scholars have criticised the Hausa video film industry for its over concentration on boy meets girl storylines revolving around romantic and domestic conflicts instead of focusing on the many other realities and challenges of northern Nigeria. The finding in Table 1 indicates that the dominance of romantic themes in Hausa video film production is probably related to audience choice which may explain the demand for such films. Hausa video films are produced with the intent to recoup investment; therefore producers will only make films on themes the audience prefer. Although critical political economists are intrigued with consistent customer consumption of bland content produced using the same formula (Baran \& Davis, 2011), the findings of Table 1 indicates that this standardised content may actually be due to audience demand. However, cultural scholars such as Adorno argue that "during consumption the masses become characterised by the commodities which they use and exchange among themselves" (Laughey, 2007, p.124). A second and very persuasive argument is that media industries push certain genres and themes while purposively neglecting others with the aim to sell an ideology and make profit and the viewers swallow what they are fed line, hook and sinker.

- RQ2. What are the motivating factors for consumption of Hausa video films among the youth of Unguwan Dosa and Kawo, Kaduna? 
Volume 1 Number 1 Maiden Issue

Table 2: Motivation for consumption of Hausa video films among Respondents

\begin{tabular}{|l|l|l|l|}
\hline MOTIVATION(S) & FREQUENCY & PERCENT & $\begin{array}{l}\text { CUMULATIVE } \\
\text { PERCENT }\end{array}$ \\
\hline Good trailers & 33 & 17.5 & 17.5 \\
\hline The released film tracks & 52 & 27.5 & 45 \\
\hline The actors & 49 & 25.9 & 70.9 \\
\hline The Producer & 16 & 8.5 & 79.4 \\
\hline The Director & 18 & 9.5 & 88.9 \\
\hline The Poster & 21 & 11.1 & 100 \\
\hline Total & 189 & 100.0 & \\
\hline
\end{tabular}

Film trailers attract $17.5 \%$ of respondents and film songs released before the actual release of the films influence up to $27.5 \%$ of the respondents to purchase films. This data explains why film songs are released sometimes up to six months before the official release of a film. This trend was most notable in the films Rariya and Mariya. The main songs Rariya and Mariya trended in every audio and video shop, intercity transport stations and radio stations. The videos of the songs were also released, sold and freely shared. As a result, reports on the social media pages of the producers showed that both films got remarkable cinema attendance for straight two weeks at Film House Cinema, Kano. The same reports are an indication that the enhanced cinema viewing increased the producers' chances of investment recoupment because other producers also adopted the same strategy. It is not surprising that as much as $25.9 \%$ of the respondents watch Hausa video films because of the actors. Some of them went as far as writing/mentioning names of specific actors; notable Ali Nuhu, Adam A. Zango, Sadiq Sani Sadiq and Umar M. Shariff. This data may indicate reasons why producers prefer certain actors more than others to cast in their films. The four actors mentioned above are the most popular, the most highly paid and also the ones most frequently cast, appearing in at least a film monthly (Mohammed, 2016). This data indicates that many of the audience of Hausa films watch based on convenience, affiliation as well as ease of understanding that comes with the familiar language of the medium. Only $8.5 \%$ patronise Hausa video films based on the production company, 9.5\% based on the director and $11.1 \%$ stated that the promotion posters are a motivation for patronage of Hausa video films.

- RQ3. What is the preferred aspect of Hausa video film content among the youth of Unguwan Dosa and Kawo, Kaduna?

Table 3: Preferred aspect of Hausa video film content among respondents

\begin{tabular}{|l|l|l|l|}
\hline PREFERRED ASPECT & FREQUENCY & PERCENT & $\begin{array}{l}\text { COMMULATIVE } \\
\text { PERCENT }\end{array}$ \\
\hline Educative content & 9 & 4.8 & 4.8 \\
\hline Comic relief & 21 & 11.1 & 15.9 \\
\hline Song and dance & 52 & 27.5 & 43.4 \\
\hline The love themes & 49 & 25.9 & 69.3 \\
\hline The suspense & 6 & 3.2 & 72.5 \\
\hline The fights & 14 & 7.4 & 79.9 \\
\hline Costumes of the actors & 26 & 13.8 & 93.7 \\
\hline
\end{tabular}


Volume 1 Number 1 Maiden Issue

\begin{tabular}{|l|l|l|l|}
\hline 2 or more options & 12 & 6.3 & 100 \\
\hline Total & 189 & 100.0 & \\
\hline
\end{tabular}

The song and dance sequences proved to be the major reason why the respondents $(27.5 \%)$ patronize Hausa video films while $25.9 \%$ choose the love themes. This data is consistent with that of Table 1 where up to $42.9 \%$ of the respondents selected romantic drama. Young people are at the age of courtship, romantic affiliations and just discovering their inner desires. The mass media is a mirror of life and audience members associate with media content that echoes their own realities and hidden desires. It is therefore not surprising that it is the most preferred genre to this sample of young people. According to $13.8 \%$ of the respondents, the costumes of the actors are what they prefer most and what attracts them to Hausa video films. The next popular option was comic relief $(11.1 \%)$ emphasizing the view of media scholars (Murdock \& Golding, 2010) that the mass media serves to douse tension accumulated by the masses from a hard day's work. Only $4.8 \%$ of the respondents watch Hausa video films because they consider them to contain certain lessons about life. Pioneer Hausa film actress Fati Mohammed in a personality interview (Taurarin mu na Kannywood) on AREWA24 $\left(7^{\text {th }}\right.$ April, 2015) cited an instance where a man called her on her mobile phone to enquire which film he can purchase for his wives so that it can influence them to live peacefully. This shows that some of the audience do look up to these films to learn about everyday life (Mohammed, 2016).

- RQ4. What are the implications of these preferences on the content of the Hausa video film industry?

The Nigerian film industry, including Kannywood (The Hausa video film industry with major roots in Kano), is purely a commercial enterprise that has been left in the hands of independent producers who are mainly traders and marketers with a sole aim of commercial gain (Zajc, 2009; Furniss, 2003). The effect of this is that many of the present filmmakers are only able to produce very predictable films with poorly scripted contents around domestic issues, witchcraft, rituals, flamboyant city living and depiction of negative western values without reasons or lessons for the society (Adeleke, 2003; Onuzulike,2007).

The literature review looked at many arguments (Chomsky, 2002; Golding and Murdock, 2000; Hardy, 2010; Hesmondalgh, 2010) which assume the audience to be an almost passive brainwashed group because it only has the right to choose within the confines of an already select number of media content. These political economy scholars argue that the audience is set up to believe it has the power to make a choice and use personal resources to choose among what is offered to it instead of getting what it needs. The major thrust of the argument is the belief that the audience is actually fed what it has been programmed to want, without understanding it is not what it needs.

However, the findings of this study indicate that audience taste might be a factor in Hausa video film production because the audience preferences were conversant with the type of content making its way out of the Hausa video industry. This is an indication that the supply of such romantic genres and dominant storylines of love may be a reaction to audience demand. The culture industry therefore has to cater to this demand because media production may be an art with a bit of social responsibility, but it is also an organised economic pursuit with the primary goal of sustenance and profit making. Content creators are therefore obliged to lean towards audience preferences if they are to recoup their investments. Contemporary production trends bear witness to this power of the audience. When certain content gets acceptance and makes sales, many similar storylines, genres and sequels crop up 
producers competing for a share of the same market. This shows that the final determinant of a media content is from how much money it generates which is dependent on audience acceptance i.e how committed the audience are to pledging personal funds in exchange for a cultural product. On the global film market, some films with beautiful storylines have been flops in the box office and failed to get recognised in the award community which is also almost entirely reliant on market intrigues and audience choice.

\section{CONCLUSION}

Hence we arrive at what this paper refers to as the 'confluence' i.e a meeting point of the culture industry and the audience, of political economy and audience selectivity. It is proven over time and beyond contest that regulations, economics and audience choice are all determinants of media content.

The first juncture looked at content production from the perspective of the $21^{\text {st }}$ century audience with access to so many media types and forms including the choice to tune in or tune out media messages where and when ever. These prefences among young people who are the main audience of the Hausa film industry may have contributed to the sustenance of the dominant shallow storylines of love triangle and domestic issues. These young people, already having an array of choices from a borderless world, have high expectations and could choose to alienate any media that chooses to impose its preferences on them. In this audiovisual $21^{\text {st }}$ century, the audience is king and the power of audience choice to select preferred options has never been this strong.

The second juncture is to assume the audience is conditioned to think it has a choice, when the reality is having a choice within limited options. History is able to establish that the Hausa video industry was set up by the experiments of young people who grew up viewing Hindi and Chinese films and therefore built their own industry by localising the foreign media they grew up knowing (Adamu, 2003; Jibril, 2003; Adamu, 2006; Mohammed, 2016). Taking these established arguments as a pedestal, this paper can also argue that Hausa video film may have already conditioned young people of what film content to prefer just as the filmmakers themselves are influenced by their love of Hindi cinema. Political economy scholars (Adorno, 1991; Chomsky, 2002; Hesmondalgh, 2010) reiterate that media industries push certain genres and themes while purposively neglecting others with the aim to sell an ideology and make profit. They further argue that the audience believe and adopt this ideology. To apply this argument to the contents of the Hausa video film industry is to identify that commercial interest may be an underlying factor in the persistence of these storylines and that the audience are only made to believe they have the power of choice on a very limited and predetermined indigenous visual world.

This study therefore concludes that the preferences of Hausa video film content among the youth of Unguwan Dosa and Kawo areas of Kaduna is influenced partly by audience selectivity and partly by political economy of the industry. It is a very borderless and dicey confluence with each juncture flowing unto the other one and the meeting point difficult to separate. This confluence may partly be a result of youth exposure to global content and partly indigenous media industries competing with the media trends of a borderless world where many cultures, many media and many contents flowing freely have become one large difficult-to-define waterfall of popular culture. 


\section{CONCLUSION AND RECOMMENDATION}

The mass media remains a major agent of socialisation and this is pronounced more than ever in today's information controlled world. An indigenous media is an opportunity for the society to address its open and salient challenges and serve as an orientation platform for young people. The Hausa video film content may be a supply to audience demand but as a big and organised media sector it should possess the social responsibility to understand that young people deserve more, that media is an agent of socialisation and should therefore address social challenges. This paper likens the Hausa video film industry to a parent that gives the child the power to always choose junk instead of feeding the child with nutritious food. A responsible parent should know how to create the much needed balance between enjoyment and requirement. This paper therefore recommends that on that point where political economy and audience selectivity meets, social responsibility should become the third juncture on the confluence of Hausa video film production.

\section{REFERENCES}

Adamu, A. U. (2005). The Political Economy of Production - Mercantile Control and Artistic Inclinations in Hausa Video Film Industry. Retrieved from http://www.academia.com

Adamu, A. U. (2006). Global influences, national flows-the influence of Hindi film music on Hausa traditional music and video films in Adamu A.U, Jibril U.F, Malam M.N, Maikaba and Ahmad G.(Eds.) Communication, Media and Popular Culture in Northern Nigeria. Proceedings of the First International Conference Organised by the Department of Mass Communication, Bayero University, Kano (12th-13th July, 2006). Zaria: Ahmadu Bello University Press.

Adeleke, A. D. (2003). Culture, art and film in African society; An evaluation. Nordic Journal of African Studies, 12(1).

Adorno, T. (1991) "Culture industry reconsidered" in Adorno, T.W and Bernstein J.M (Eds) The Culture Industry; Selected Essays on Mass Culture (2 ${ }^{\text {nd }}$ Edition). London. Routledge.

Ali, B. (2003). "Historical review of film and Hausa drama and thier impact on the origin, development and growth of Hausa home videos in Kano" in Adamu, A.U, Adamu, Y.M \& Jibril U.F (Eds.), Hausa home videos: Technology, economy and society. Kano: Centre for Hausa cultural studies.

Baran, S.\& Davis, D. K. (2011). Mass communication theory; Foundations, ferment and future. Toronto: Wadsworth Publishing.

Chomsky, N (20002). Media Control. The Spectacular achievements of Propaganda $\left(^{\text {nd }}\right.$ Edition). Penguin Random House.

Clark, B. (1998). Political economy. A comparative approach ( $2^{\text {nd }}$ Edition). London: Praeger Publishers. 
Cohen, S. (1972). Folk Devils and Moral Panics: The creation of Mods and Rockers. London: MacGibbon \& Kee.

Drotner, K (1992). "Modernity and media panics"in Skovmand, M and Schroeder, K.C (Eds.), Media cultures: reappraising transnational media.. London: Routledge.

Fiske S.T and Taylor S.E (1991) Social Cognition (2nd Edition). New York: McGraw Hill.

Furniss, G. (2003). Hausa popular literature and video film: The rapid rise of cultural

Production in times of economic decline. Working Papers (No 27). Johannes

Gutenberg University, Department of Anthropology and African Studies, Mainz.

Gillespe, M. (2005) "Beyond the living room. Rethinking media audiences" in Gillespie M. (Ed.) Media Audiences .Maidenhead: Open University Press.

Golding, P and Murdock, G (2000). Culture, communication and political economy in Curran, J and Gurevitch, M (Eds.), Mass media and society. London: Arnold.

Hall, S. (1980). "Encoding/Decoding" in Hall H, Hobson D, Lowe A and Willis P (Eds.), Culture, Media, Language. London: Hutchinson.

Hardy, J. (2010). "The contribution of critical political economy" in J. Curran (Ed.) Media and society ( $5^{\text {th }}$ Edition). London: Bloomsbury.

Hesmondhalgh, D. (2010). "Media industry studies, media production studies" in Curran J (Ed.), Media and society (5th edition) London: Bloomsbury.

Jibril, U. F. (2003). "Small technologies, the changing trends in Hausa home videos production" in Adamu, A.U, Adamu, Y.M \& Jibril U.F (Eds.). Hausa home videos: Technology, economy and society. Kano. Centre for Hausa Cultural Studies.

Knobloch-Westerwick, Silvia. 2015. "Building Blocks of the Selective Exposure Paradigm." In Choice and Preference in Media Use: Advances in Selective Exposure Theory and Research, 3 -24. New York: Routledge.

Larkin, B. (1997). Indian films and Nigerian lovers, media and creation of parralel modernities. Africa, 67(3), 406-407.

Laughey, D. (2007). Key themes in media theory ( $1^{\text {st }}$ Edition). McGraw Hill. Open University Press.

Livingstone sonia as Media audiences, interpreters, users, in: Gillespie, M, Media Audiences, 2. Maidenhead, UK : Open University Press, 2005, pp. 9-50.

Maikaba, B. (2003). "Cinematic conventions and the influence of western (Hollywod) and Indian (Bollywood) cinema in contemporary Hausa home video" in Adamu, A.U, Adamu, Y.M \& Jibril U.F (Eds.). Hausa home videos: Technology, economy and society. Kano: Centre for Hausa cultural studies. 
Volume 1 Number 1 Maiden Issue

Maikaba, B. (2006). "Globalisation, northern media and the changing landscape in Nigeria" in Adamu A.U, Jibril U.F, Malam M.N, Maikaba B and Ahmad G.(Eds.) Communication, media and popular culture in northern Nigeria. Zaria:Ahmadu Bello University Press.

Murdock G \& Golding P. (1991). "Culture Communication and Political Economy" in Curran, J and Gurevitch, M (Eds.), Mass media and society. London: Edward Arnold.

Onuzulike, U. (2007). Nollywood. The influence of the Nigerian movie industry on African culture. The Journal of Human Communication:A Journal of the Pacific and Asia Communication Association, 10 (3).

Stroud, N.J (2017). "Selective Exposure Theories" in Kenski, K and Jamieson, K, H (Eds) The Oxford Handbook of Political Communication. Retrieved from https://www.oxfordhandbooks.com/view/10.1093/oxfordhb

Zajc, M. (2009). Nigerian video film cultures. Anthropological Notebooks, 15(1). 